\title{
Effect of pre-partum feed supplementation on post-partum ovarian activity, milk production and calf growth of small holder dairy Cattle in Cameroon
}

\author{
Pougue Henri Bayemi*, Munji Victorine Nsongka, Isabelle Leinyuy, Edward Cottington Webb, \\ Justin Mbanya Nchadji, Daniel Cavestany and Mike Bryant
}

\begin{abstract}
Seventy-two cows were selected for an on-farm study on the effect of feed supplementation before calving on milk production, ovarian activity and calf growth of Holstein, indigenous Red Fulani cows and their crosses. Prepartum feed supplementation was done using cotton seed cake (80\%), maize (18\%), bone meal (1\%) and kitchen salt (1\% $\mathrm{NaCl}$ ). Supplementation levels consisted of a low supplemen-tation fed at $1 \mathrm{~kg}$ per animal per day and high supplementation fed at $2 \mathrm{~kg}$ per animal per day. In addition, Red Fulani cows received the supplements in two different ways namely a prepartum supplementation consisting of $1 \mathrm{~kg}$ per cow per day and pre- and post-partum supplementation consisting of $1 \mathrm{~kg}$ per cow per day before calving and $1 \mathrm{~kg}$ per cow per day post-partum up to 30 days after calving. Blood samples were analysed using ELISA Progesterone kits to determine the length of post-partum anoestrus. Results show that prepartum levels of feeding did not have any effect $(P>0.05)$ on body condition score $(B C S)$ at 12 weeks after calving, calf birth weight, average daily weight gain of calves, milk pro-duction and post-partum anoestrus. High BCS at calving was shown to influence BCS at 12 weeks of lactation. Holstein cows had bigger calves $(\mathrm{P}<0.01)$ at birth $(45 \mathrm{~kg})$ compared to traditional cows $(36 \mathrm{~kg})$ and crosses $(34 \mathrm{~kg})$. There was little benefit of pre-partum supplementation on the parameters investigated in this study. Consequently, low income farmers are advised to concentrate their efforts of supplementation early in lactation.
\end{abstract}

Keywords Cameroon · ELISA · Progesterone · Prepartum supplementation $\cdot$ Prostaglandins

\footnotetext{
P. H. Bayemi (*), M. V. Nsongka, I. Leinyuy, J. M. Nchadji Institute of Agricultural Research for Development, P O Box 2067, Yaounde, Cameroon

e-mail: hbayemi@yahoo.fr

E. C. Webb

Head department of animal and wildlife science, University of Pretoria, Pretoria, South Africa

e-mail: webb@up.ac.za

D. Cavestany

Instituto Nacional de Investigación Agropecuaria, INIA La Estanzuela, C.Correos 39173, Montevideo 70000, Uruguay e-mail: dancaves@internet.com.uy

\section{Bryant}

Department of Agriculture, University of Reading, Berkshire, UK
}

\section{Introduction}

Supplementation with concentrates is a key aspect to improve productivity in tropical dairy production. Not only does sup-plementation help sustain high milk yields of cows, but it also improves the fertility of these cows (Mukasa-Mugerwa 1989). Effective nutritional management during the transition period has long been recognised as having a major impact on health and productivity of dairy cows (Jon Schoonmaker 2013). In developing countries, low income farmers do not always supplement milking cows, yet they expect them to produce adequate quantities of milk and also complete involution and return to the reproductive phase in the shortest possible time. Potential most farmers who supplement their cows do so by giving a small quantity of concentrate during milking. Studies have shown that cows have a critical body condition score at mating, below which conception rates are reduced if the animals are still in a negative energy balance (Haresign 1980). The energy status of the cow, seen by the change in the body condition score, also affects fertility (Anon 1984). A cow's body condition score level and change during gestation can be associated with energy balance, and her ability to meet the needs of maintenance, lactation and foetal growth which 
can potentially affect the offspring's future performance as a milk-producing cow (Jon Schoonmaker 2013). These studies were carried out in high yielding cows in commercial farms. There is little information on the effect of pre-partum supple-mentation and body condition score at calving on production parameters in small holder dairy systems. The purpose of this study was to investigate the effects of pre-partum supplemen-tation, breed and body condition score on the resumption of normal oestrus activity, milk production and calf growth of milking cows in small-scale dairy systems in Cameroon.

\section{Material and methods}

\section{Study site}

The Western Highlands region of Cameroon is located in the mid- and high altitude zone of the country, which lies between latitudes $5^{\circ} 20^{\prime}$ and $7^{\circ}$ north and longitude $9^{\circ} 40^{\prime}$ and $11^{\circ} 10^{\prime}$ east. The surface area of the province is $17,910 \mathrm{~km}^{2}$ covering $1 / 6$ th of the country's land area. Altitudes range from 300 to $3000 \mathrm{~m}$ above sea level. There are two main seasons: a dry season from November to mid-March and a rainy season from mid-March to October. Rainfall ranges between 1300$3000 \mathrm{~mm}$, with a mean of $2000 \mathrm{~mm}$. Minimum and maximum temperatures range between $15.50{ }^{\circ} \mathrm{C}$ and $24.5{ }^{\circ} \mathrm{C}$, respectively, although temperatures above $30^{\circ} \mathrm{C}$ are not uncommon.

\section{Animals and experimental design}

Seventy two cows were randomly selected from dairy farms in the region. They were bred by natural mating and confirmed pregnant by rectal palpation at about 6 to 8 months of gestation. The experimental animals consisted of 26 Red Fulani (Bos indicus), 28 Holstein (Bos taurus) and 18 crosses (Bos taurus $x$ Bos indicus). The potential effects of differences in forage availability were assumed to be reflected in the body condition score of cows.

Holstein cows were stall fed in a zero grazing system. Forage was cut, chopped and fed to cows in feeding troughs. This forage consisted mainly of Guatemala grass (Trypsacum laxum), Desmodium spp. and Elephant grass (Pennisetum purpureum). Crosses and indigenous cattle grazed either on Brachiaria spp., on native Sporobolus africanus or on marginal pastures. Cows in the pre-partum supplementation group were fed with a supplement consisting of cotton seed cake ( $80 \%)$, maize (18\%), bone meal $(1 \%)$ and kitchen salt $(1 \% \mathrm{NaCl})$. Holstein and crosses were randomly allocated to a $2 \times 2$ factorial design, breed $\times$ level of feeding. Supplementation levels consisted of a low fed at $1 \mathrm{~kg}$ per animal per day and high fed at $2 \mathrm{~kg}$ per animal per day (T1 to T4). Red Fulani cows were fed in two different ways, namely, pre-partum supplementation consisting of $1 \mathrm{~kg}$ per cow per day (T5) and pre- and post-partum supplementation consisting of $1 \mathrm{~kg}$ per cow per day before calving and $1 \mathrm{~kg}$ per cow per day post-partum up to 30 days after calving (T6). The supplement for this last period was given during milking, whereas for other groups, the supplement was given in the morning from 30 days before the expected calving date until calving (Fig. 1). When a cow calved after the expected day, it did not receive any additional supplement other than the 30 or $60 \mathrm{~kg}$ planned. And when it calved before the expected day, experimental supplementation stopped. Some farmers in the zero grazing and semiextensive systems continued to supplement their cows after calving. This variable was included in the statistical analysis. Information such as cow identification, lactation number and breed were obtained prior to the beginning of the study. Body condition scores (BCS) were done using the 1 to 5 scale (Edmonson et al. 1989). Daily milk production, calf birth weight and average daily weight gain of calves were recorded after calving. Red Fulani cows were not milked.

Progesterone level analysis

Starting from 4 days post-partum until 12 weeks postpartum, weekly blood samples were collected in 10-ml sample tubes and kept on ice during transportation to the laboratory. Blood samples were centrifuged and the serum frozen at $-20{ }^{\circ} \mathrm{Celsius}$ until analysed. Progesterone was analysed by means of standard ELISA Progesterone kits from Clinpro International Co. LLC. (Union City, USA, CA 94587, EH- 511) to determine re-initiation of ovarian activity. The mini-mum detectable level of progesterone in the assay was $0.05 \mathrm{ng} / \mathrm{ml}$ (Clinpro International 2005). Intra-assay precision varied from 2.4 to $7.1 \%$ while interassay precision varied from 2.6 to $12.6 \%$. The assay could detect progesterone levels of up to $50 \mathrm{ng} / \mathrm{ml}$, above which a diluent is required. The low control had values ranging from

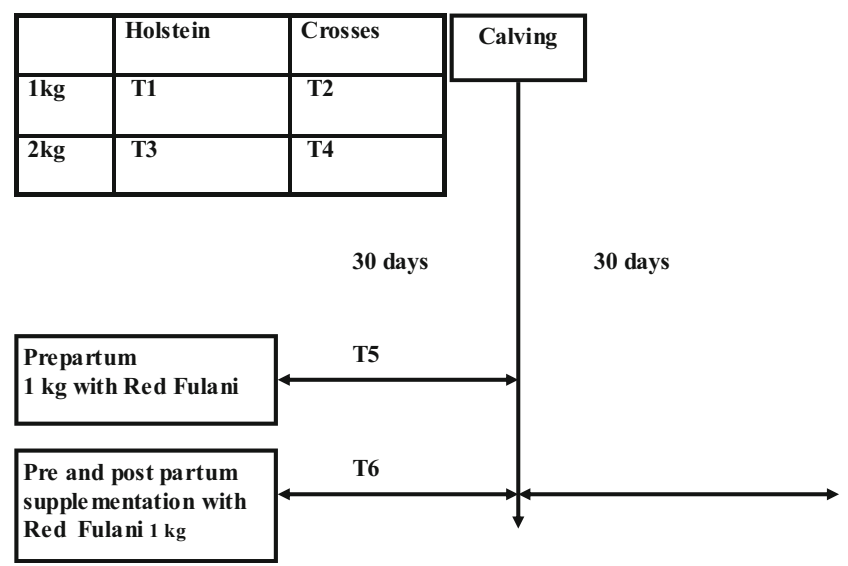

Fig. 1 Desposition of the six experimental treatments 
Table 1 Effect (lsmeans \pm sem) of pre-partum level of feeding on BCS and calf weight

\begin{tabular}{llllll}
\hline & BCS at 12 weeks & $\begin{array}{l}\text { Calf birth } \\
\text { weight }(\mathrm{kg})\end{array}$ & $\begin{array}{l}\text { Average daily } \\
\text { weight gain }(\mathrm{g})\end{array}$ & $\begin{array}{l}\text { Average daily milk } \\
\text { production (litres) }\end{array}$ & $\begin{array}{l}\text { Post-partum return } \\
\text { to oestrus (days) }\end{array}$ \\
\hline Low level of feeding & $2.6 \pm 1.42 \mathrm{a}$ & $37 \pm 1.4 \mathrm{a}$ & $124 \pm 14 \mathrm{a}$ & $8.3 \pm 1.6 \mathrm{a}$ & $79 \pm 13 \mathrm{a}$ \\
High level of feeding & $2.3 \pm 1.38 \mathrm{a}$ & $40 \pm 1.4 \mathrm{a}$ & $91 \pm 19 \mathrm{a}$ & $8.1 \pm 1.5 \mathrm{a}$ & $70 \pm 15 \mathrm{a}$ \\
\hline
\end{tabular}

Means with the same letter are not significantly different

3.5 to $7.5 \mathrm{ng} / \mathrm{ml}$ and the high 20 to $39.5 \mathrm{ng} / \mathrm{ml}$.

Statistical analysis

A general linear model (GLM) in SAS and Statistical Analyses (2002)) was used to test the effect of the four variables listed below on calf birth weight, average daily weight gain of calves up to 12 weeks of age, milk yield within the same period, days required to return to oestrus and body condition score of milking cows at 12 weeks postpartum. The variables included in the model were as follows: level of pre-partum feeding, body condition score at calving, breed and post-partum supplementation. Body condition score at calving was divided into two groups: less than 3 and from 3 upwards. Post-partum level of feeding was also considered in two groups: $\leq 3 \mathrm{~kg}$ per cow per day and $>3 \mathrm{~kg}$ per cow per day, up to a maximum of $6 \mathrm{~kg}$ per cow per day.

Within breed comparison of the effect of the level of feeding on the variables studied was done. Means were compared using the Student-Newman-Keuls Test. The statistical models were as follows:

$\gamma_{\mathrm{ijk} l}=\mu+F_{\mathrm{i}}+B_{\mathrm{j}}+C_{\mathrm{k}}+S_{1}+e_{\mathrm{ijkl}}$

where $\gamma_{\mathrm{ijkl}}$ is the dependant variable (milk yield, daily weight gain of calves, length of post-partum anoestrus and body condition score at 12 weeks post-partum), $\mu$ is the overall mean, $F_{\mathrm{i}}$ is the level of pre-partum feeding, $B_{\mathrm{j}}$ is the cow breed, $C_{\mathrm{k}}$ is the body condition score at calving, $S_{1}$ is level of post-partum supplementation and $e_{\mathrm{ijkl}}$ is the random error.

$\gamma_{\mathrm{ijk}}=\mu+F_{\mathrm{i}}+B_{\mathrm{j}}+C_{\mathrm{k}}+e_{\mathrm{ijk}}$ where ${ }_{\mathrm{ijkl}}$ is the calf birth weight, $\mu$ is the overall mean, $F_{\mathrm{i}}$ is the level of pre-partum feeding, $B_{\mathrm{j}}$ is the cow breed, and $C_{\mathrm{k}}$ is the body condition score at calving, $e_{\mathrm{ijk}}$ is the random error.

\section{Results}

Results show that there was no significant effect $(P>0.05)$ of pre-partum level of feeding on the variables studied in this experiment, although feeding more concentrates prior to calv-ing tended to lead to higher milk production within the first 3 months of lactation (Table 1). Similarly, the birth weights of calves were slightly higher when cows were fed more con-centrates before calving, although this result was not statisti-cally significant $(P>0.05)$.

The results confirm that BCS at calving significantly influenced BCS at 12 weeks after calving $(P=0.014)$. Cows in a better body condition at calving had more body condition 12 weeks post-partum (Table 2). The condition score at calving did not affect the other variables as expected in this study $(P>0.05)$. In addition to the improvement in body weight and body condition, supplementation also seemed to have positively influenced reproductive performance (Zollitsch et al. 2011).

Breed significantly influenced $(P<0.001)$ calf birth weights, although crosses did not have significantly larger birth weights than traditional breeds (Table 3). Average daily weight gains of calves were slightly higher for the Holstein breed, but the difference was not significant. Traditional cows suckled their calves and as such, they were not milked. Furthermore, it was found that their return to ovarian activity was similar to the other breeds $(P>0.05)$.

Table 2 Effect of body condition score at calving (lsmeans \pm sem)

\begin{tabular}{llllll}
\hline & BCS at 12 weeks & $\begin{array}{l}\text { Calf birth } \\
\text { weight }(\mathrm{kg})\end{array}$ & $\begin{array}{l}\text { Average daily } \\
\text { weight gain }(\mathrm{g})\end{array}$ & $\begin{array}{l}\text { Average daily milk } \\
\text { production (litres) }\end{array}$ & $\begin{array}{l}\text { Post-partum return } \\
\text { to oestrus (days) }\end{array}$ \\
\hline $\mathrm{BCS}<3$ & $2.4 \pm 0.16 \mathrm{a}$ & $38 \pm 1.3 \mathrm{a}$ & $105 \pm 14 \mathrm{a}$ & $8.9 \pm 1.2 \mathrm{a}$ & $69 \pm 11 \mathrm{a}$ \\
$\mathrm{BCS}>3$ & $2.9 \pm 0.19 \mathrm{~b}$ & $40 \pm 1.6 \mathrm{a}$ & $110 \pm 19 \mathrm{a}$ & $8.7 \pm 1.5 \mathrm{a}$ & $68 \pm 13 \mathrm{a}$ \\
\hline
\end{tabular}

Means with the same letter are not significantly different 
Table 3 Effect (lsmeans \pm sem) of breed on cow and calf production and reproductive performance

\begin{tabular}{llllll}
\hline & BCS at 12 weeks & $\begin{array}{l}\text { Calf birth } \\
\text { weight }(\mathrm{kg})\end{array}$ & $\begin{array}{l}\text { Average daily } \\
\text { weight gain }(\mathrm{g})\end{array}$ & $\begin{array}{l}\text { Average daily milk } \\
\text { production (litres) }\end{array}$ & $\begin{array}{l}\text { Post-partum return } \\
\text { to oestrus (days) }\end{array}$ \\
\hline Traditional & $2.9 \pm 0.4 \mathrm{a}$ & $36 \pm 1.7 \mathrm{a}$ & $106 \pm 39 \mathrm{a}$ & Not milked & $76 \pm 12 \mathrm{a}$ \\
Holstein & $2.3 \pm 0.13 \mathrm{a}$ & $45 \pm 1.6 \mathrm{~b}$ & $134 \pm 12 \mathrm{a}$ & $12 \pm 0.9 \mathrm{a}$ & $55 \pm 9 \mathrm{a}$ \\
Crosses & $2.8 \pm 0.18 \mathrm{a}$ & $34 \pm 1.9 \mathrm{a}$ & $83 \pm 17 \mathrm{a}$ & $9 \pm 1 \mathrm{~b}$ & $56 \pm 9 \mathrm{a}$ \\
\hline
\end{tabular}

Means with the same letter are not significantly different

On the other hand, there was no evidence $(P>0.05)$ that post-partum supplementation had any influence on BCS at 12 weeks post-partum, average daily weight gain of calves, milk yield or time required to return to oestrus post-partum (Table 4). However, there were indications that high levels of concentrate feeding of lactating cows led to marginally higher weight gains of calves $(P=0.08)$. Supplementation of newly calved cows tended to increase milk production, although this was not statistically significant $(P>0.05)$.

In order to investigate the variability within breeds, analy-ses similar to the ones above were done within each breed to investigate the effect of the level of feeding on the variables considered in this work. The results were not different com-pared to the between breed comparisons.

\section{Discussion}

Condition score is related to the level of feeding. In this experiment, BSC at calving did not affect return to ovarian activity. This result agrees with that reported by Bourchier et al. (1987) who showed that condition score at calving did not affect conception rates and therefore return to oestrus until condition score was below 1.5. This level of BSC was not observed for cows in the present study. Although not significant, there were indications that cows with greater BCS at calving produced less milk. Cavestany et al. (2003) showed a negative correlation between BCS and milk production. However, BCS at calving strongly influenced BCS at 12 weeks lactation. Stalker et al. (2006) a $1 \mathrm{~s}$ of o u $\mathrm{d}$ that feeding supplement prepartum improved BCS pre-calving and pre-breeding and increased the percentage of live calves at weaning. These results indicate that within the last third of gestation, cows should be fed adequately in order to ensure a sound BCS at calving which correlates with a good nutritional state of the animal even after calving.

The effect of supplementation before calving yielded no additional improvements. However, logic would suggest that feeding some supplement before calving will help the cow to increase forage digestibility and therefore feed efficiency especially with low quality feeds commonly found in the tropics. Perhaps one explanation for a lack of observed effect was the relatively small difference between treatments in the level of feed supplied. It seems that it would have been better to have levels of 0 and $2 \mathrm{~kg}$, rather than 1 and $2 \mathrm{~kg}$. That would have possibly increased the chance of observing an effect. But farmers were not willing to participate as a $0 \mathrm{~kg}$ control as they would have gained nothing from the experiment. Farmers regarded participation in the experiment as a way to get concentrates for free and would not have adhered to an experimental design with $0 \mathrm{~kg}$ concentrate.

Chamberlain and Wilkinson (1996) suggested that 10 days before calving, the cows should be put on a diet similar to that for the medium-yielding cows in the milking herd, as 2 weeks before and 2 weeks after calving are the most important of the productive cycle.

Holstein cattle have a large frame, and they generally produce bigger calves even in challenging environments. Although the birth weights of calves are not expected to be as high as in their original region, they still outweigh traditional Cameroonian breeds and their crosses. No evidence of heterosis was observed in birth weights, as

Table 4 Effect (lsmeans \pm sem) of postpartum supplementation on BCS and calf weight and post-partum ovarian activity

\begin{tabular}{lllll}
\hline Level of feeding & BCS at 12 weeks & $\begin{array}{l}\text { Average daily } \\
\text { weight gain }(\mathrm{g})\end{array}$ & $\begin{array}{l}\text { Average daily milk } \\
\text { production (litres) }\end{array}$ & $\begin{array}{l}\text { Post-partum return } \\
\text { to oestrus (days) }\end{array}$ \\
\hline$<3 \mathrm{~kg}$ & $2.5 \pm 0.15 \mathrm{a}$ & $106 \pm 14 \mathrm{a}$ & $7 \pm 0.8 \mathrm{a}$ & $61 \pm 6 \mathrm{a}$ \\
3 to $6 \mathrm{~kg}$ & $2.9 \pm 0.24 \mathrm{a}$ & $109 \pm 23 \mathrm{a}$ & $9 \pm 1.2 \mathrm{a}$ & $64 \pm 11 \mathrm{a}$ \\
\hline
\end{tabular}

Means with the same letter are not significantly different 
crossbred animals had lighter weight offspring than did local animals. This may be because these crosses are not from the $F_{1}$ generation. Also, the breed of sire was not considered in the analysis, and perhaps, indigenous animals were carrying a greater proportion of calves sired by Holsteins. The small difference in birth weights may show that these can adequately be used in crossing with the Holstein breed without fear of an increasing problem of calving difficulties.

Traditional cows were not milked. They were therefore able to suckle their young as naturally as possible. Their production was therefore not recorded. Meanwhile, crossbred cows, although they grazed, were partially milked. Their calves could not receive enough quantities of milk and tended to show lower weight gains. It is worth mentioning that Holstein calves were bucket fed and their weight gains will not adequately reflect milk production of their mothers but milk offered by the farmers. As such, average daily weight gains of calves will not adequately reflect the effect of treatments.

Post-partum supplementation, as expected, tended to lead to higher weight gain of calves as well as higher milk produc-tion. But in this study, the tendency was not significant $(P>0.05)$. Stalker et al. (2006) also found that calves born to dams fed supplement pre-partum had similar birth weight but greater weaning weight.

The overall mean length of post-partum anoestrus was 64 days. However, $25 \%$ of cows showed a persistent corpus luteum. This is an indication of infections and it shows the need for veterinary intervention for many cows in these systems. Post-partum anoestrus was lower in this study compared to the work of Msangi et al. (2004) w i t h low supplementation leading to a period of $110 \pm 9$ days and high supplementation $87 \pm 7.6$ days. Similar results were reported by Cavestany et al.

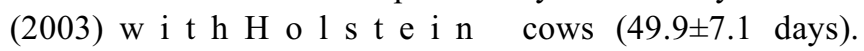
Fagan and Roche (1984) found an early resumption of ovarian activity in Holstein cows in a pasture-based production system.

Though there is evidence that good pre-partum nutrition shortens the length of post-partum anoestrus (Selk et al. 1988; Wright et al. 1992), there are also conflicting reports which may be reflected in the interactions among pre- and post-partum nutrition, negative energy balance, BCS, milk yield and suckling, as well as other environmental factors that influence duration of postpartum anoestrus (Montielc and Ahuja 2005).

Post-partum return to oestrus may not depend exclusively on BCS at calving but on other factors such as BCS post-partum and health status. Wiltbank et al.(1964) found that breeding cows must be in an im-proving body condition during the breeding period.
This was confirmed by Wiltbank (1977) and Haresign (1984). Animals losing weight between calving and breeding usually have decreased conception rates (Anon 1984). Therefore, adequate feeding at the early stage of lactation is crucial even in small-scale dairy-ing. Owing to the fact that supplementation before calving did not show much influence on milk yield or return to oestrus, it will be more profitable to small-scale farmers with limited financial means to adequately supplement milking cows within the first months of lactations rather than divert this supplement to the period before calving.

Acknowledgments This work was sponsored by the International Atomic Energy Agency (IAEA) and the African Development Bank. We express our gratitude to Sali Django, Apiembo Fopa, Njong Vincent and Fonguh Emmanuel who helped in data collection. The views expressed in this paper are those of the authors.

Conflict of interest The authors declare that they have no conflict of interest.

\section{References}

ANON, 1984. Dairy herd fertility Ref Book 259. London, HMSO

Bourchier, C.P., Garnsworthy, P.C., Hutchinson, J.M., Benton, T.A., 1987. The relationship between milk yield, body condition and reproductive performance in high yielding dairy cows (Abstr). Animal Production 44,460.

Cavestany, D., Corea, E., Silva, D., Meikle, A., 2003. Dairy cattle reproduction in tropics. Breed differences and metabolic profiles. In IAEA. Regional coordination meeting, Asuncion, Paraguay, 21st -26 th July.

Chamberlain, A.T., Wilkinson, J.M., 1996. Feeding the dairy cow. Chalcombe publications, UK, pp 151.

CLINPRO INTERNATIONAL CO. LLC., 2005. Progesterone Enzyme immunoassay test kit. No EH-511. Handbook.

Edmonson, A.J., Lean, L.J., Weaver, L.D., Farver, T., Webster, G., A, 1989. Body condition scoring chart for Holstein daily cow. Journal of Dairy Science 72, 68-78

Fagan, J.G., Roche, J.F., 1984. Reproductive activity in post partum dairy cows. 11th Int. Congr. Anim. Rep. A. I., Illiniois, USA 2:28.

Haresign, W., 1980. Body condition score, milk yield and reproduction in cattle. Recent advances in animal nutrition. London, Butterworths, P. 107.

Haresign, W., 1984. Underfeeding and reproduction: Physiological mechanisms. In: C Chemineau, D Gauthier and J Thimonier (eds), Reproduction des ruminants en zone tropicale. INRA Publication No. 20. INRA (Institut national de la recherche agronomique), Paris, France, pp. 339-365

Jon Schoonmaker., 2013. Effect of maternal nutrition on calf health and growth. Proceedings from the 2013 Tri-State Dairy Nutrition conference.

Montielc, F., Ahuja, C., 2005. Body condition and suckling as factors influencing the duration of post-partum anestrus in cattle: a review. Animal Reproduction Science 85, 1-26.

Msangi, B.S.J., Bryant, M.J., Nkya, R., Thorne, P.J., 2004. The effects of a short-term increase in supplementation on reproductio9n 
performance in lactating crossbred dairy cows. Tropical Animal Health and Production 36 No. 8, 775-787.

Mukasa-Mugerwa, E., 1989. A review of reproductive performance of female Bos Indicus (Zebu) cattle. ILCA Monograph No 6, Addis Abba.

SAS, Statistical Analyses System, 2002. SAS Institute Inc., Cary NC, USA

Selk, G.E., Wettemann, R.P., Lusby, K.S., Oltjen, J.W., Mobley, S.L., Rasby, R.J.,Garmendia, J.C., 1988. Relationship among weight change, body condition and reproductive performance of range beef cows. J. Anim. Sci. 66, 3153-3159.

Stalker, L. A., Adams, D. C., Klopfenstein, T. J., Feuz, D. M., Funston, R. N., 2006. Effects of pre- and post-partum nutrition on reproduction in spring calving cows and calf feedlot performance. J Anim Sci. 84, $2582-2589$.
Wiltbank, J. N. Rowden, W. W. Ingalls, J. E., Zimmerman, D. R., 1964. Influence of postpartum energy levels on reproductive performance of Hereford cows restricted in energy intake prior to calving. Journal of Animal Science 23, 1049-1053.

Wiltbank, J. N., 1977. Effect of level of nutrition on growth and reproduction of beef females. Georgia Nutrition Conference, 16-18 February. pp. 138-146.

Wright, I.A., Rhind, S.M., Whyte, T.K., Smith, A.J., 1992. Effects of body condition at calving and feeding level after calving on $\mathrm{LH}$ profiles and the duration of the post-partum anoestrous period in beef cows. Anim. Prod. 55, 41-46.

Werner Zollitsch., Wurzinger, M., Tekeba Esheti Nege., 2011. Effects of strategic dietary supplementation on local Fogera and crossbred dairy cows in Northwestern Ethiopia. Final report to a cooperative project $\mathrm{P} 180$ 